\title{
A Study of Synchronous vs. Asynchronous Collaborative Design in Students' Learning Motivation
}

\author{
Yong-Ming Huang, Chia-Sui Wang, and Yi-Chun Liu
}

\begin{abstract}
Collaborative applications of cloud computing have garnered considerable attention in recent years, but little effort has been devoted to exploring the effects of them on students' learning motivation. In this study, we use Google Docs to support students in collaboratively designing the structure of the website. In this quasi-experimental design, 49 university students participated in the study. The participants were divided into two groups, an "experimental group" and a "control group." The experimental group was able to simultaneously design the structure of the website, namely synchronous design, while the control group designed the website asynchronously. The results show that synchronous design was not particularly helpful in motivating students' learning when compared to asynchronous design.
\end{abstract}

Index Terms-Synchronous, asynchronous, collaborative design, learning motivation.

\section{INTRODUCTION}

In recent years, it has been shown that cloud computing is one of the most important technologies as tools for educational innovative applications [1], [2]. Specifically, cloud computing is a service-oriented architecture, in which various software and hardware resources are regarded as services to provide users [3]. Hence, users can use these rich services over the Internet to drive many educational applications. For example, many software resources such as word processing, spreadsheets, or presentations have been developed as services on the Internet, in which users can directly access the software through the Internet instead of installing special software on their computer. More importantly, these services are tailored to fit the needs of education, such as Google Apps for Education, so that instructors may use the services to facilitate their teaching and learning purposes [4], [5]. In addition to software services, researchers also indicated that the hardware services can be used as an empowering tool to advance the development of the educational technology in some cash-strapped areas due to the pay-as-you-go mode of cloud

Manuscript received March 5, 2014; revised May 5, 2014. This work was financially supported by the National Science Council of the Republic of China under Contract NSC 102-2511-S-041-001-, NSC 102-2511-S-041-005-, and NSC 102-2511-S-041-004-.

Yong-Ming Huang is with the Department of Applied Informatics and Multimedia, Chia Nan University of Pharmacy and Science, Taiwan (e-mail: ym.huang.tw@gmail.com).

Chia-Sui Wang is with the Department of General Education, Chia Nan University of Pharmacy and Science, Taiwan (e-mail: lcwang@mail.chna.edu.tw).

Yi-Chun Liu is with the Department of Applied Foreign Languages, Chia Nan University of Pharmacy and Science, Taiwan (e-mail: ycliu715@gmail.com). computing [6]. In this manner, the institutions of the areas do not need to spend much time and money to build and maintain their own information technology infrastructure [7]. Overall, cloud computing can be used to advance many educational applications.

Among innovative applications, collaboration is the most potential applications for education. Collaboration is a process, in which "individuals and/or groups work together on a practical endeavor' [8]. Specifically, individuals can use various information and communication technologies (ICTs) to establish a virtual space where they can collaboratively create, share, or discuss. In the past, such ICTs include discussion forums or wikis that can only provide individuals with asynchronous collaboration, namely, individuals collaboratively edit the content at different times in a shared workspace [9]. Hence, the interaction of asynchronous collaboration is not immediate and spans longer periods of time. Now, with the development of cloud computing, ICTs have been enhanced to synchronous mode [8], [9]. For example, Google Docs drawings already make it possible for multiple users to chat while editing a drawing simultaneously. This means that by using such modern ICTs, the interaction among collaborators may be made closer and further promote their collaboration. That is to say, such modern ICTs may be applied to educational applications such collaborative learning. For example, Calvo et al. applied Google Docs to support students in writing collaboratively in large cohorts [5]. Overall, the modern ICTs enable students to realize collaborative learning and add social capabilities when they are engaged in learning.

Although there has been much research on cloud computing services, little effort has been devoted to applying them to support students' collaborative learning. Based on the survey of cloud computing services in the previous paragraph, it can be observed that the collaboration is one of the important educational applications due to the development of cloud computing [5], [8]. Collaboration enables students to share and exchange ideas to collaboratively solve problems of learning. More importantly, such collaboration services lead students to more readily embrace learning, since they no longer need to face the problems of learning alone. However, so far there have been no studies that support student experiences with collaborative learning in a collaborative service, and this is the gap in the literature that this study aims to address.

In this study, we used a collaborative service to support the students in collaboratively designing the structure of the website and further to explore their learning motivation. To explore the effectiveness of the collaborative service on students' learning motivation, a quasi-experimental research design was constructed. A learning motivation questionnaire 
[10] was used to explore the learning motivation of students. Finally, a series of analyses were carried out to examine the collaborative service and to draw conclusions about the analyses.

\section{METHOD}

\section{A. Research Question}

Our investigation into the applicability of collaborative service on synchronous collaborative learning was structured around the following research question:

- Is the effectiveness of synchronous design on students' learning motivation similar to that of asynchronous design?

\section{B. Participants}

The participants were from two classes of a university in Tainan City, Taiwan, in which a total of 49 students enrolled in this study. Among them, 25 students from one class were designated as the experimental group, while 24 students from the other class were the control group.

\section{Collaborative Learning Tool}

The Google Docs was used as the collaborative learning tool to support students in designing the structure of the website. It is one of the famous cloud services that provides users with word processing service. More importantly, the Google Docs enables users to collaboratively edit their diagrams or documents on the cloud. During collaboration, they can also use track changes function to track who made the change and compared the differences between different versions. Hence, the Google Docs could be used to assist students in collaboratively designing the structure of the website, as shown in 0 .

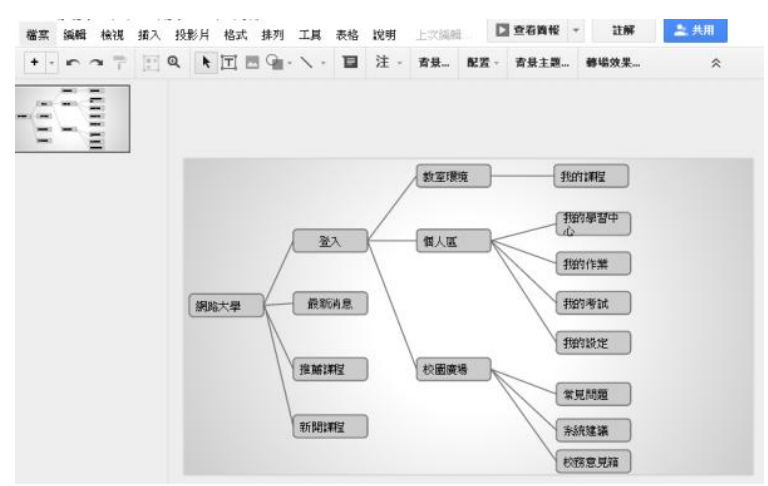

Fig. 1. The students use the Google Docs to design the structure of the website.

\section{Measurement Tool}

The measurement tool was a questionnaire used to measure the learning motivation regarding the website design. The questionnaire for learning motivation was modified from instructional materials motivation scale (IMMS) developed by Keller [10]. The original IMMS comprises four subscales, namely attention, relevance, confidence, and satisfaction. The attention subscale has 12 items, the relevance and confidence subscales both have 9 items and the satisfaction subscale has 6 items. In this study, we modified and deleted some items, in which the modified IMMS has 25 items, as shown 00shows that the result for reliability of the questionnaire is acceptable, since all the values meet the required levels.

TABLE I: THE QUESTIONNAIRE FOR LEARNING MOTIVATION

\begin{tabular}{|c|c|}
\hline Scale & item \\
\hline Attention 1 & Designing the structure of the website got my attention \\
\hline Attention 2 & Designing the structure of the website is very attractive \\
\hline Attention 3 & $\begin{array}{l}\text { Designing the structure of the website is so abstract, I do } \\
\text { not want to learn }\end{array}$ \\
\hline Attention 4 & Designing the structure of the website is boring \\
\hline Attention 5 & $\begin{array}{l}\text { I am curious what is the design of the structure of the } \\
\text { website }\end{array}$ \\
\hline Attention 6 & I was tired of designing the structure of the website \\
\hline Attention 7 & $\begin{array}{l}\text { Designing the structure of the website enables me to learn } \\
\text { something unexpected }\end{array}$ \\
\hline Attention 8 & $\begin{array}{l}\text { Learning how to use tools to design the structure of the } \\
\text { website attracts my attention }\end{array}$ \\
\hline Relevance 1 & $\begin{array}{l}\text { Designing the structure of the website is related to things I } \\
\text { already knew }\end{array}$ \\
\hline Relevance 2 & Designing the structure of the website is important to me \\
\hline Relevance 3 & $\begin{array}{l}\text { Designing the structure of the website is relevant to my } \\
\text { interests }\end{array}$ \\
\hline Relevance 4 & $\begin{array}{l}\text { Designing the structure of the website can help me to } \\
\text { develop a website }\end{array}$ \\
\hline Relevance 5 & Designing the structure of the website is worth knowing \\
\hline Relevance 6 & $\begin{array}{l}\text { Designing the structure of the website is related to my } \\
\text { major }\end{array}$ \\
\hline Relevance 7 & Designing the structure of the website is useful to me \\
\hline $\begin{array}{l}\text { Confidence } \\
1\end{array}$ & Designing the structure of the website is easy for me \\
\hline $\begin{array}{l}\text { Confidence } \\
2\end{array}$ & Designing the structure of the website is difficult to me \\
\hline $\begin{array}{l}\text { Confidence } \\
3\end{array}$ & Designing the structure of the website is complicated to me \\
\hline $\begin{array}{l}\text { Confidence } \\
4\end{array}$ & $\begin{array}{l}\text { I was confident that I can design the structure of the } \\
\text { website }\end{array}$ \\
\hline $\begin{array}{l}\text { Confidence } \\
5\end{array}$ & $\begin{array}{l}\text { I could not really understand quite a bit of the design of the } \\
\text { structure of the website }\end{array}$ \\
\hline $\begin{array}{l}\text { Satisfaction } \\
1\end{array}$ & $\begin{array}{l}\text { Completing the exercises in the design of the structure of } \\
\text { the website gave me a satisfying feeling of } \\
\text { accomplishment }\end{array}$ \\
\hline $\begin{array}{l}\text { Satisfaction } \\
2\end{array}$ & $\begin{array}{l}\text { I enjoy the design of the structure of the website so much } \\
\text { that I would like to know more about this topic }\end{array}$ \\
\hline $\begin{array}{l}\text { Satisfaction } \\
3\end{array}$ & I really enjoy designing the structure of the website \\
\hline $\begin{array}{l}\text { Satisfaction } \\
4\end{array}$ & $\begin{array}{l}\text { The feeling of designing the structure of the learning } \\
\text { website is good }\end{array}$ \\
\hline $\begin{array}{l}\text { Satisfaction } \\
5\end{array}$ & It was a pleasure to design the structure of the website \\
\hline
\end{tabular}
5

\begin{tabular}{cc} 
& TABLE II: RELIABILITY ESTIMATES \\
\hline Scale & Reliability (Cronbach's alpha) \\
\hline Attention & .73 \\
Relevance & .86 \\
Confidence & .63 \\
Satisfaction & .80 \\
Total scale & .90 \\
\hline
\end{tabular}

\section{E. Procedure}

0 shows the experimental design of this study. At the beginning of the learning activity, the students took the pre-test. The purpose of the pre-test was to measure the students' learning motivation regarding the website design, i.e., to examine whether the two classes had similar level of learning motivation. After the pre-test, the two classes of students went through learning activities that lasted a total of 150 minutes, where they learned about the basics of website design. After the learning activity, the two groups of students were assigned to design the structure of three websites, in 
which the students were grouped randomly into several groups. Each group comprised 2-3 students. In the experimental group, each student of each group has a desktop computer, hence they can synchronously design the structure of the website through the Google Docs. On the other hand, in the control group, all students of each group only have one desktop computer, that is, they cannot design the structure of the website synchronously. Once the designing activity was completed, the students took the post-test in order to measure their learning motivation.

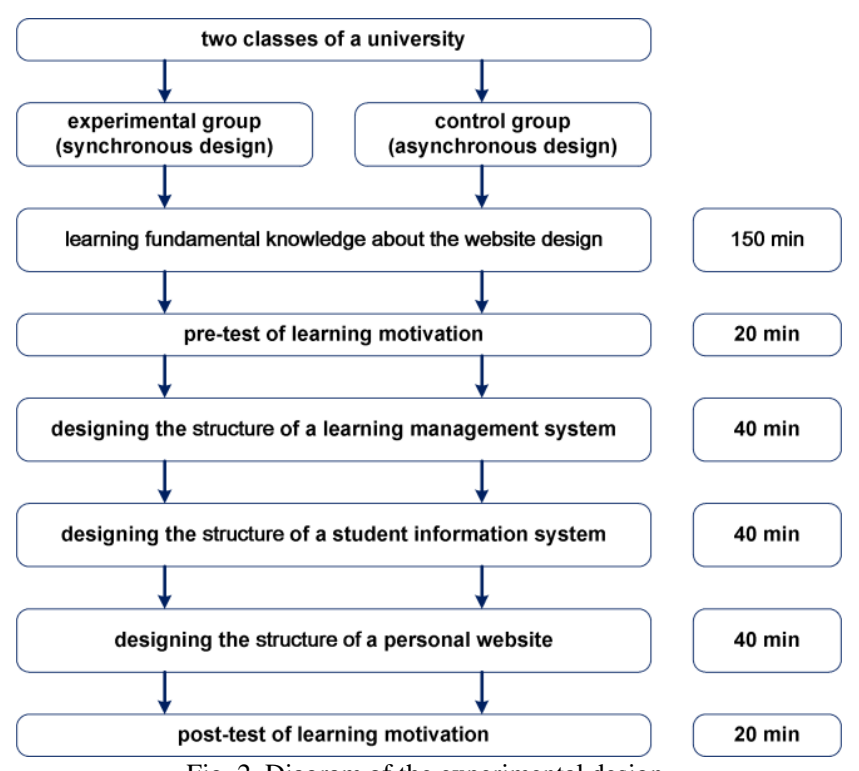

\section{RESULTS}

In this study, due to the fact that the sample is small size and non-normal distribution, Mann-Whitney $U$ test was applied to conduct data analysis. In contrast with t-test, the Mann-Whitney $U$ test does not require large samples and normal distribution. Hence, the Mann-Whitney U was used instead of the t-test.

TABLE III: MANN-WhitNEY U TEST RESUlt OF THE PRE-TEST

\begin{tabular}{|c|c|c|c|c|c|}
\hline Scale & Group & $N$ & Mean & S.D. & $p$ \\
\hline \multirow{2}{*}{ Attention } & $\begin{array}{l}\text { Experimental } \\
\text { group }\end{array}$ & 25 & 3.31 & .39 & \multirow[t]{2}{*}{.09} \\
\hline & $\begin{array}{l}\text { Control } \\
\text { group }\end{array}$ & 24 & 3.16 & .26 & \\
\hline \multirow{2}{*}{ Relevance } & $\begin{array}{l}\text { Experimental } \\
\text { group }\end{array}$ & 25 & 3.37 & .50 & \multirow[t]{2}{*}{.06} \\
\hline & $\begin{array}{l}\text { Control } \\
\text { group }\end{array}$ & 24 & 3.14 & .25 & \\
\hline \multirow{2}{*}{ Confidence } & $\begin{array}{l}\text { Experimental } \\
\text { group }\end{array}$ & 25 & 3.00 & .28 & \multirow[t]{2}{*}{.25} \\
\hline & $\begin{array}{l}\text { Control } \\
\text { group }\end{array}$ & 24 & 3.07 & .28 & \\
\hline \multirow{2}{*}{ Satisfaction } & $\begin{array}{l}\text { Experimental } \\
\text { group }\end{array}$ & 25 & 3.29 & .43 & \multirow[t]{2}{*}{.26} \\
\hline & $\begin{array}{l}\text { Control } \\
\text { group }\end{array}$ & 24 & 3.12 & .28 & \\
\hline \multirow{2}{*}{ Total scale } & $\begin{array}{l}\text { Experimental } \\
\text { group }\end{array}$ & 25 & 3.24 & .28 & \multirow[t]{2}{*}{.09} \\
\hline & $\begin{array}{l}\text { Control } \\
\text { group }\end{array}$ & 24 & 3.12 & .21 & \\
\hline
\end{tabular}

Prior to the designing activity, participants were subjected to a pre-test to assess their learning motivation regarding the website design. 0shows the Mann-Whitney $U$ test results for the pre-test, where both the mean and standard deviation of the total scale were 3.26 and .29 in the experimental group; 3.13 and .21 in the control group. The Mann-Whitney $U$ test results showed that no significant difference existed between the two groups in the pre-test $(p=.11>.05)$, implying the two groups of students had similar learning motivation regarding the website design.

After the designing activity, the Mann-Whitney $U$ test was used to test the difference in post-test between the two groups. 0shows the results, where the test scores of the total scale in the experimental group (mean $=3.29, \mathrm{SD}=.41$ ) were not significantly higher $(p=.16>.05)$ than the control group (mean $=3.12, \mathrm{SD}=.18)$. This result indicated that compared to asynchronous design, synchronous design is not particularly helpful in assisting students in enhancing their learning motivation regarding the website design.

TABLE IV: MANN-WHitney U TEST RESUlt of THE POST-TEST

\begin{tabular}{|c|c|c|c|c|c|}
\hline Scale & Group & $N$ & Mean & S.D. & $p$ \\
\hline \multirow{2}{*}{ Attention } & $\begin{array}{l}\text { Experimental } \\
\text { group }\end{array}$ & 25 & 3.21 & .36 & .91 \\
\hline & $\begin{array}{l}\text { Control } \\
\text { group }\end{array}$ & 24 & 3.16 & .21 & \\
\hline \multirow{2}{*}{ Relevance } & $\begin{array}{l}\text { Experimental } \\
\text { group }\end{array}$ & 25 & 3.40 & .51 & .21 \\
\hline & $\begin{array}{l}\text { Control } \\
\text { group }\end{array}$ & 24 & 3.19 & .38 & \\
\hline \multirow{2}{*}{ Confidence } & $\begin{array}{l}\text { Experimental } \\
\text { group }\end{array}$ & 25 & 3.14 & .40 & .58 \\
\hline & $\begin{array}{l}\text { Control } \\
\text { group }\end{array}$ & 24 & 3.02 & .21 & \\
\hline \multirow{2}{*}{ Satisfaction } & $\begin{array}{l}\text { Experimental } \\
\text { group }\end{array}$ & 25 & 3.35 & .47 & .05 \\
\hline & $\begin{array}{l}\text { Control } \\
\text { group }\end{array}$ & 24 & 3.10 & .25 & \\
\hline \multirow{2}{*}{ Total scale } & $\begin{array}{l}\text { Experimental } \\
\text { group }\end{array}$ & 25 & 3.27 & .39 & .32 \\
\hline & $\begin{array}{l}\text { Control } \\
\text { group }\end{array}$ & 24 & 3.12 & .17 & \\
\hline
\end{tabular}

\section{CONCLUSIONS AND IMPLICATIONS}

Our research applied the Google Docs to assist students in synchronously designing the structure of the website. To explore the effectiveness of the Google Docs system on synchronous design in comparison to asynchronous design, a quasi-experimental research design was constructed. The results revealed that the synchronous design and asynchronous design have the same effectiveness on students' learning motivation.

\section{ACKNOWLEDGMENT}

The authors would like to thank the National Science Council of the Republic of China for financially supporting this research under Contract No. NSC 102-2511-S-041 -005 and NSC 102-2511-S-041 -004 -.

\section{REFERENCES}

[1] C. S. Wang, Y. M. Huang, and Y. M. Huang, "Interactive e-learning with cloud computing framework," Lecture Notes in Electrical Engineering, vol. 182, pp. 311-316, 2012.

[2] Y. M. Huang, C. S. Wang, J. Z. Guo, H. Y. Shih, and Y. S. Chen, "Advancing collaborative learning with cloud service," Lecture Notes in Electrical Engineering, vol. 253, pp. 717-722, 2013. 
[3] M. Armbrust, A. Fox, R. Griffith et al., "A view of cloud computing," Communications of the ACM, vol. 53, no. 4, pp. 50-58, 2010.

[4] M. Al-Zoube, "E-learning on the cloud," International Arab Journal of e-Technology, vol. 1, no. 2, pp. 58-64, 2009.

[5] R. A. Calvo, S. T. O'Rourke, J. Jones, K. Yacef, and P. Reimann, "Collaborative writing support tools on the cloud," IEEE Transactions On Learning Technologies, vol. 4, no. 1, pp. 88-97, 2011.

[6] N. Sultan, "Cloud computing for education: A new dawn," International Journal of Information Management, vol. 30, no. 2, pp. 109-116, 2010

[7] L. M. Vaquero, "Educloud: Paas versus Iaas cloud usage for an advanced computer science course," IEEE Transactions on Education, vol. 54, no. 4, pp. 590-598, 2011.

[8] M. S. E. Scale, "Cloud computing and collaboration," Library Hi Tech News, vol. 26, no. 9, pp. 10-13, 2009

[9] A. Poulovassilis and F. Xhafa, "Building event-based services for awareness in P2P groupware systems," in Proc. the Eighth International Conference on P2P, Parallel, Grid, Cloud and Internet Computing. Compiegne, France.

[10] J. M. Keller, Motivational Design for Learning and Performance: The ARCS Model Approach, New York: Springer, 2010.

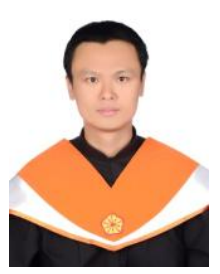

Yong-Ming Huang is currently an assistant professor in the Department of Applied Informatics and Multimedia at Chia-Nan University of Pharmacy and Science, Taiwan. He received his Ph.D. degree from the Department of Engineering Science at National Cheng Kung University. His research interests include web-based learning, game-based learning, mobile learning and ubiquitous learning.

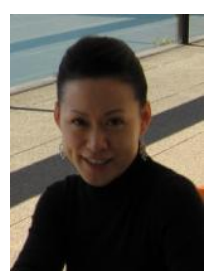

Chia-Sui Wang is currently a vice president in Chia-Nan University of Pharmacy and Science, Taiwan. She had been a Director of Chia Nan University. She received her Ed.D in Teachers College from Columbia University. She received the M.Ed at Harvard Graduate School of Education. Her current research interests include computer-assisted learning, teaching and learning strategies.

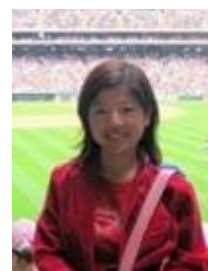

Yi-Chun Liu is currently an assistant professor in the Department of Applied Foreign Languages at Chia Nan University of Pharmacy \& Science, Tainan, Taiwan. She received her Ph.D. in Teaching English as a Second Language (TESL) from Texas A\&M University, USA Her research interests are in the field of computer-assisted language learning, vocabulary learning, English for tourism, and sports English. 